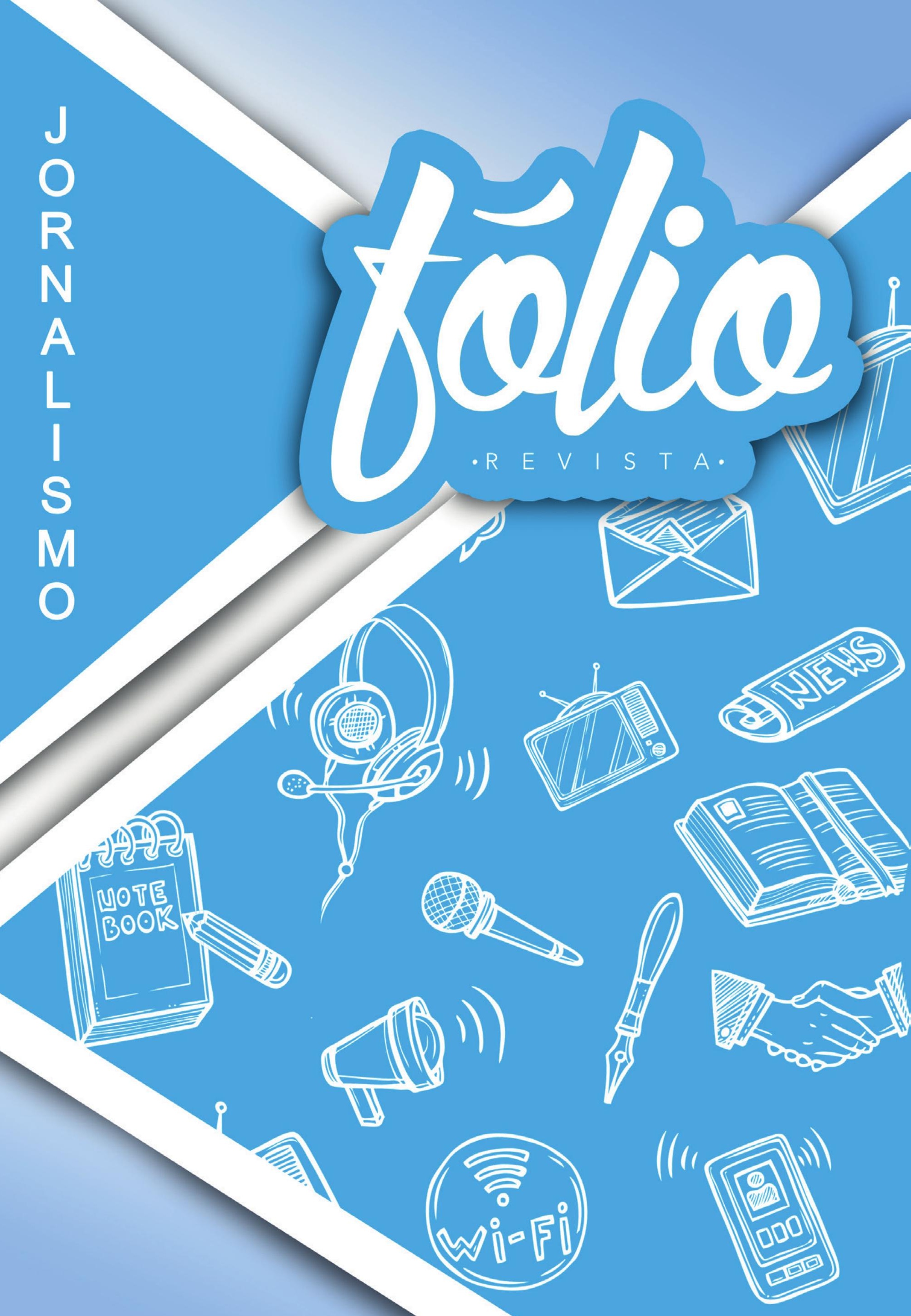




\title{
Convergência e discurso no caso Casey Heynes: um estudo comparativo entre a mesma personagem no Youtube e na televisão
}

\section{Convergence and discourse in the Casey Heynes' case:}

a comparative study among the same character in Youtube and television

\author{
Cristiane Weber ${ }^{1}$
}

\section{Resumo}

Este artigo tem como objetivo analisar, do ponto de vista da convergência e do discurso, a construção de uma reportagem veiculada no programa $A$ Current Affair, da rede australiana $A B C$, a qual se apropriou de um vídeo da Internet para transformar a personagem principal em um herói. A pesquisa se desenvolve tendo como corpora o vídeo bruto, publicado no Youtube, de um jovem australiano respondendo a uma ação de bullying; e o vídeo da reportagem citada. Esta análise é de natureza exploratória, com vertente qualitativa, utilizando-se como método o comparativo. Por fim, conclui-se que a reportagem, da maneira como promoveu uma convergência entre meios - imprimiu um ethos de herói ao jovem Casey, legitimado por um discurso específico para apresentá-lo. Tal ethos apresenta o rapaz como vítima e ao mesmo tempo representante de uma geração de pessoas que sofreram com o bullying e ainda sofrem em sala de aula.

Palavras-Chave: Bullying. Discurso. Convergência. Youtube. Televisão.

\section{Abstract}

This paper aims to analyze, from the point of view of convergence and discourse, the construction of a report published in the program A Current Affair, of the Australian network ABC, which has appropriated an Internet video to transform the main character into a hero. The research develops as a corpora the raw video, published on Youtube, of a young Australian responding to a bullying action; and the video of the report quoted. This analysis is exploratory, with a qualitative aspect, using as comparative method. Finally, it is concluded that the report, in the way it promoted a convergence between media - impressed a hero ethos on the young Casey, legitimized by a specific discourse to present it. Such ethos presents the boy as a victim and the same time represents a generation of people who have suffered from bullying and still suffer in the classroom.

Keywords: Bbullying. Discourse. Convergence. Youtube. Television.

\footnotetext{
1 Professora de Comunicação e doutoranda em Processos e Manifestações Culturais na Universidade Feevale.
} 


\section{Introdução}

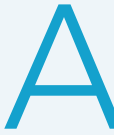

s emissoras de televisão, por muito tempo, necessitaram única e exclusivamente de equipes com repórteres e cinegrafistas nas ruas para os registros mais comuns ou insólitos do dia-a-dia. Com as mídias que já se tornaram parte do dia a dia e seus gadgets de alta tecnologia, qualquer cidadão comum está apto a publicar na rede um vídeo de sucesso, que pode ou não ser aproveitado pelos veículos de comunicação. E os principais estão publicados, quase que em sua totalidade, na plataforma Youtube. Quando esta surgiu em 2005, fundada por ex-funcionários do site de comércio on-line Pay-Pal, foram necessários apenas dois anos para que o site se tornasse o mais acessado no quesito entretenimento do Reino Unido. Nos dias atuais, os dados estatísticos da plataforma já contabilizam mais de um bilhão de usuários, que visualizam bilhões de horas de conteúdos diversos, em mais de 80 idiomas diferentes. Tamanha aderência confere ao Youtube a classificação de plataforma multifuncional, na qual vídeos dos mais diferentes gêneros e durações são compartilhados.

Alguns, porém, são mais visualizados e comentados que outros. Nesta revolução de publicações, a maioria de demandas pessoais, o Youtube se tornou um vilão e um aliado das mídias ditas tradicionais. Burgess e Green (2009) classificam que a tal rede provocou uma ruptura dos negócios atuais e surgiu como um novo ambiente de poder midiático. Entre os vídeos mais procurados, em levantamento dos próprios autores, estão os que mostram brigas em ambiente escolar, reunindo características de atração bastante específicas: juventude e moralidade, que provocam o que os autores classificam como "pânico midiático". Para os autores,

Essa centralização do pânico midiático é exemplificada por histórias de "ciberintimidação" uso de tecnologias digitais para intimidar pessoas, especialmente por meio da publicação de vídeos humilhantes ou ofensivos ou do uso de vídeos para documentar e enaltecer atos de violência (BURGESS e GREEN, 2006, p.40)
Foi em uma postagem deste cunho que, em 16 de março de 2011, sob o título Victim Fights Back In NSW Sydney School | 'Casey', um vídeo com pouco mais de quarenta segundos se transformou em um fenômeno da Internet.

Neste, o jovem Casey Heynes, então com treze anos, responde às provocações de um colega que o intimidava e aplicou-lhe um golpe (fig. 1) que arremessou o outro ao chão com extrema violência.

Figura 1 - Casey aplica o golpe no colega na saída do período de aula

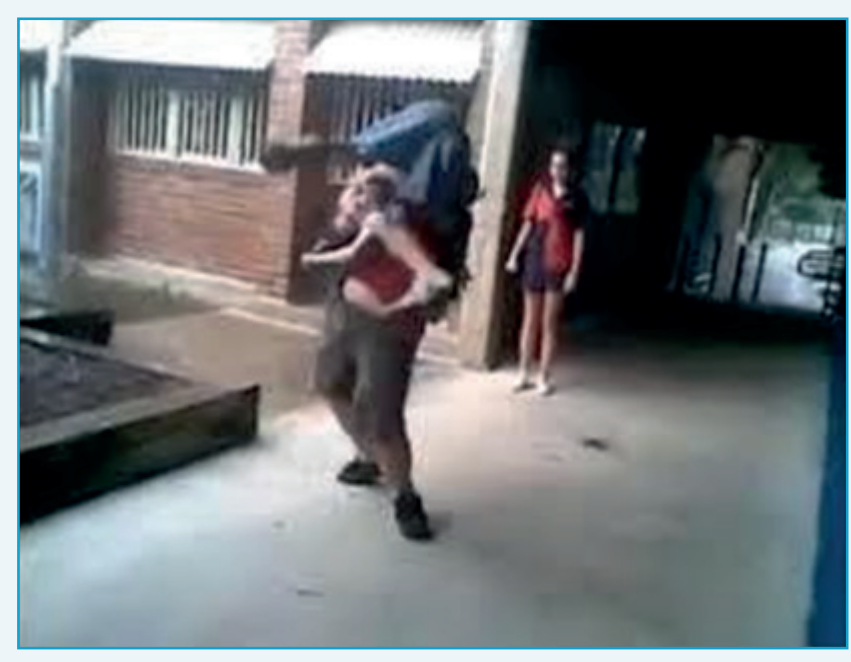

Fonte 1 - Cena extraída do vídeo no portal Youtube

O vídeo se tornou um fenômeno em pouco tempo. A partir de julho de 2012, houve um crescimento exponencial na curva de acessos. Milhares de comentários foram publicados no próprio Youtube e outros tantos chegaram a Casey de variadas formas: através de sua página na rede social Facebook, por envio direto de mensagens de vídeo e e-mails. Foi a partir de tamanho sucesso que se iniciou um processo de convergência, permeado por um discurso ideológico e parcial, quando o programa de televisão A Current Affair, da rede australiana $A B C$, resolveu transformar aquele conteúdo em uma história.

A partir das imagens publicadas e já com a compreensão de que aquele era um fragmento de mídia bastante acessado e compartilhado, a produção do programa foi até a personagem principal do vídeo para aprofundar a história, mostrando ao mundo, em uma reportagem de doze mi- 
nutos (tempo considerável para um programa de televisão), um Casey ingênuo, vítima de bullying e marcado por histórias familiares conturbadas. Se antes da veiculação da reportagem o vídeo já havia sido comentado e amplamente compartilhado, a partir da reportagem do programa A Current Affair houve um crescimento ainda maior no número de acessos, alçando o vídeo à categoria de um dos mais acessados na plataforma.

O caso Casey Heynes é um dos tantos que surgem no ambiente web, são amplamente compartilhados e se transformam em um discurso específico na televisão. A questão é: o que faz do vídeo da reportagem um propulsor de acessos de outro vídeo no Youtube? Como ocorre o processo de convergência neste sentido? Que rastros discursivos da reportagem dão suporte a esta convergência e como permitiram que Casey fosse transformado em um herói para outras vítimas de bullying em todo o mundo? Para compreendermos tal atração pelo vídeo e a construção da reportagem do ponto de vista do discurso e da convergência, buscou-se apoio na fundamentação teórica da análise do discurso de Maingueneau (2013) e de convergência de Jenkins (2006), entre outros, propondo interfaces teóricas e pontos de contato entre ambas. Este referencial serve de base para compreendermos como tal reportagem se constrói, tendo a investigação sido apoiada na metodologia comparativa, em uma pesquisa de natureza exploratória que será apresentada em etapa posterior deste artigo. A seguir, se apresenta uma síntese dos aportes teóricos dos autores acima citados, para posterior análise dos dados.

\section{Olhares teóricos para a convergência}

Talvez um dos modelos mais abarcadores para compreender como acontece um processo de convergência parta das concepções de Jenkins (2006). O autor identificou tal fenômeno proporcionado pelo desenvolvimento tecnológico e pelas atividades da sociedade desenvolvidas nas novas mídias, além de perceber que a convergência atribui a estes veículos um poder de transforma- ção das indústrias midiáticas. Assim, quando a televisão se apropria de um conteúdo do Youtube, delineando uma nova roupagem e um novo conteúdo, temos um processo colaborativo, proporcionando à mídia que se apropria (neste caso a televisão) o poder de imprimir ao vídeo outras referências e reapresentações. Buscando múltiplas manifestações e audiência no processo de ressignificação do vídeo de Casey, o processo de convergência no caso citado buscou interpretações e reapresentações de um objeto inicial, com o objetivo de atrair o interesse dos telespectadores. $O$ mesmo acontece para tantos outros casos nascidos no ambiente online, como o menino Marcos de Santa Catarina e seu carrinho de lomba, popularizando o bordão "Pode vir, Marcos".

Se em proposições teóricas anteriores a convergência era vista como uma maneira de distribuir um conteúdo de forma diferente, hoje já percebe este fenômeno como algo mais complexo. Jenkins (2006) chama a atenção para o uso dos smartphones, quando se reforça a ideia de que a convergência passa pelo uso e pelas relações estabelecidas entre as ideias e os suportes. Reforçando este caráter cultural da convergência, Jenkins (2009, p.30) explica que "a convergência não ocorre por meio de aparelhos, por mais sofisticados que venham a ser. A convergência ocorre dentro dos cérebros de consumidores individuais e em suas interações sociais com os outros".

Neste sentido, percebe-se um fenômeno comumente citado pelo autor: de receptor de conteúdos, o telespectador passou a ser um produtor destes conteúdos. Se antes as televisões tinham a figura do pauteiro como a principal na identificação de assuntos relevantes, hoje chegam diariamente a estes espaços o conteúdo produzido por cidadãos comuns, que estão fora das redações. Com a profusão de "pautas" postadas na rede, houve inclusive uma reconfiguração da profissão jornalista. Cada vez mais adaptados com a nova realidade, estes profissionais estão aprendendo a ver o os cidadãos como extremamente participativos e ativos no processo de construção da reportagem.

Se hoje há uma compreensão destes novos métodos de produção, nos primeiros anos de Youtube as percepções foram diferentes, perme- 
adas inclusive por processos de repúdio à nova mídia. Um exemplo disso é citado por Burgess e Green (2009): na véspera do ano novo de 2007, os programas australianos da atualidade Today $\mathrm{Ni}$ ght e A Current Affair transmitiram matérias sobre os videoclipes mais populares de 2007, descrevendo o site tanto como um repositório mundial de "momentos incríveis, vergonhosos e, às vezes, muito perigosos" ao redor do mundo como uma plataforma de lançamento para "muitos novos astros". Porém, apenas algumas semanas depois, percebendo a concorrência de acessos e o interesse dos jovens pela nova mídia, os mesmos programas passaram a destinar tempo considerável com reportagens sobre ciberintimidação no Youtube, acusando-o de ser, na verdade, algo muito danoso - um site mal administrado de comportamentos criminosos, antiéticos e patológicos dedicados à juventude como categoria de risco. No entanto, Burgess e Green (2009) alertam que, ao passo de que repudiam o acesso e a postagem, os próprios veículos de comunicação tratam de valorizar o que é postado e dar a estes vídeos uma nova dimensão, atraindo um número maior de pessoas interessadas no conteúdo.

[...] é importante considerarmos o quanto esses discursos de pânico moral nos debates públicos podem acabar incentivando práticas ainda mais perigosas, descuidadas ou nocivas, ao passo de que não colaboram em nada para exercer uma influência positiva sobre as normas sociais que agem dentro das redes sociais que usam o Youtube como plataforma (BURGESS; GREEN, 2009, p. 42).

Quando a apropriação de um conteúdo digital pela televisão acontece, temos o que Jenkins (2009) irá chamar de narrativas transmidiáticas e estratégias transmidiáticas. No primeiro caso, temos em destaque um conteúdo que privilegia a narrativa; no segundo vemos a ubiquidade de informações adicionais, mas não tão ligada a uma sequência narrativa. De acordo com Jenkins (2009), a narrativa transmidiática acontece quando uma história é contada a partir de um fragmento, abordando perspectivas diferentes, complementando a primeira. Esta teoria é complementada pelo olhar de Lèvy (1996), pelo conceito da virtualização. Segundo o autor, este processo ocorre quando se reinventa uma cultura nômade, não por uma volta ao paleolítico nem às antigas civilizações de pastores, mas quando se faz surgir um meio de interações sociais onde as relações se reconfiguram com um mínimo de inércia. De acordo com ele,

Quando uma pessoa, uma coletividade, um ato, uma informação se virtualizam, eles se tornam não-presentes, se desterritorializam [...] É verdade que não são totalmente independentes do espaço-tempo de referência, uma vez que devem sempre se inserir em suportes físicos e se atualizar aqui ou alhures, agora ou mais tarde (LÈVY, 1996, p. 21)

É o que acontece no processo de convergência do vídeo sobre Casey quando é reconfigurado na televisão, processo que detalharemos a seguir.

\section{Análise do discurso midiático: mídium, cenografia e ethos}

Todos os dias, ao nos depararmos com reportagens, programas de entrevistas e outros gêneros televisivos, mal percebemos que por trás de imagens e sons existe uma construção midiática estratégica, formalmente construída para atrair telespectadores. Até poucos anos, os meios de comunicação como rádio e televisão eram vistos tão somente como aparelhos caseiros diferentes: um se trata de uma pequena caixa com osciladores de estações e o outro, um pouco maior, carrega um seletor de canais e a possibilidade de acompanharmos o que é contado com imagens, inicialmente em escalas de cinza, hoje possíveis em alta resolução. Maingueneau (2013) nos mostra que esta percepção é errônea e ultrapassada. Se antes víamos o texto de comunicação como uma sequência de frases sem sentido, hoje há outra percepção vigente. Segundo o autor,

Hoje, estamos cada vez mais conscientes de que o mídium não é um simples "meio" de transmissão do discurso, mas que ele impõe coer- 
ções sobre seus conteúdos e comanda os usos que deles podemos fazer. $\bigcirc$ mídium não é um simples meio, um instrumento para transportar uma mensagem estável: uma mudança importante do mídium modifica o conjunto de um gênero de discurso (MAINGUENEAU, 2013, p.82)

Isso significa que a mensagem do veículo não é um processo linear e fechado. A ideia de que um apresentador esteja em uma bancada de um telejornal e leia a notícia, após buscar exprimi-la de alguma forma e redigida aleatoriamente, na busca de um encontro com um destinatário, é parte do passado e um tanto vazia. Por trás de tudo isso, existe um dispositivo comunicacional que integra o mídium e condiciona a constituição de um texto. Quando o vídeo de Casey saiu da plataforma Youtube e foi veiculado na televisão, também passou por um processo de convergência do discurso. Neste contexto, percebemos mudanças importantes nas programações da televisão. Se em 1950, por exemplo, as programações eram feitas ao vivo e davam considerável espaço a programas de auditório, hoje os programas são muito mais curtos, com projetos comprados e tornam as escolhas muito mais personalizadas do que de consumo de massa. Assim, a programação tem como objetivo atrair a atenção e a empatia do telespectador.

Complementando esta teoria, Charaudeau (2012) nos diz que o discurso é resultado de circunstâncias diversas em que se fala ou se escreve: a identidade daquele que fala e daquele a quem se dirige, a relação de intencionalidade que os liga e as condições físicas da troca, com a maneira pela qual se fala. Para tanto, há um termo que o próprio autor define como mecânica de construção de sentido, que nomeia, qualifica, argumenta e modaliza. $\bigcirc$ ato de informar enquadra-se nesta mecânica porque descreve (identifica/qualifica fatos), conta (reporta acontecimentos) e explica (fornece as causas destes fatos e acontecimentos). Quando se trata de transmitir uma notícia, leva-se em conta, de acordo com o autor, a identidade do receptor-destinatário (neste caso o telespectador), seus saberes e o efeito de sentido que se quer causar, o que se qualifica como um processo de transação. Consoante Charaudeau,

$\mathrm{O}$ ato de informar participa deste processo de transação, fazendo circular entre os parceiros um objeto de saber que, em princípio, um possui e o outro não, estando um deles encarregado de transmitir e o outro de receber, compreender, interpretar, sofrendo ao mesmo tempo uma modificação com relação ao seu estado inicial de conhecimento (CHARAUDEAU, 2012, p. 41).

Associado a esta estratégia, estão a cenografia e todo um processo identitário que se quer construir para o telespectador. Para chegarmos a conclusões e interpretações diversas a partir do que é veiculado todos os dias na televisão e nos corpora que avaliaremos a seguir, é preciso compreender que a construção de uma reportagem, tal como quaisquer outros gêneros discursivos, é permeada por aquilo que Maingueneau (2013) irá classificar como cenografia e ethos, dentro das chamadas cenas de enunciação.

A cenografia diz respeito a um enlaçamento paradoxal. De acordo com o autor, "todo discurso, por sua manifestação mesma, pretende convencer pela cena de enunciação que o legitima". Associando a palavra cenografia ao termo cenário, podemos imaginar que os elementos de imagem, iluminação, posicionamento do entrevistador, trilha sonora e cortes de edição, entre outros, fazem parte dos elementos de cenografia de uma reportagem. Através destes elementos, esta pode provocar sentimentos de emoção, identificação, repúdio, espanto, entre outros. A voz impressa nas reportagens, tecnicamente chamada de "off", está diretamente vinculada a todos os elementos que estão sendo mostrados, ou seja, jamais estão desconectados.

Maingueneau ressalta que

(...) a cenografia não é simplesmente um quadro, um cenário, como se o discurso aparecesse inesperadamente no interior de um espaço já construído e independente dele: é a enunciação que, ao se desenvolver, esforça-se para constituir progressivamente o seu próprio dispositivo de fala (MAINGUENEAU, 2013, p. 97-98)

O autor destaca que, deste modo, a cenografia é ao mesmo tempo a fonte do discurso e aquilo que ele engendra. Em um processo de duali- 
dade, ela legitima o enunciado que, por sua vez, também deve legitimá-la, estabelecendo que esta cenografia onde nasce a fala é precisamente a cenografia exigida para enunciar como convém, segundo o caso. Quando unimos os efeitos desejados pela cenografia e pelo discurso - estes imbricados - chega-se ao conceito de ethos de Maingueneau, que representa um sujeito situado para além do texto. Por meio da enunciação, revela-se a personalidade do enunciador.

Seja fiel ou não à verdadeira intenção da personagem a ser exposta, o ethos proposto por uma reportagem é construído pela forma na qual este é exposto através do discurso. Um criminoso, por exemplo, pode ser mostrado como um assassino frio e calculista ou vítima de uma sociedade distorcida ou abusos na infância. Da forma como o qual sua história é contada, haverá uma interferência direta e persuasiva na recepção dos telespectadores. Este ethos será construído, principalmente, pelo conceito de tom, que dá autoridade ao que é dito. Ao assistir a uma reportagem e se manifestar de acordo com que é esperado pela emissora, o telespectador se torna um fiador do que é dito. Neste processo, a própria personagem confere a si um ethos, que pode ser incutido no telespectador. Maingueneau afirma que

O universo de sentido propiciado pelo discurso impõe-se tanto pelo ethos como pelas ideias que transmite; na realidade, estas ideias se apresentam por intermédio de uma maneira de dizer que remete a uma maneira de ser, à participação imaginária em uma experiência vivida (MAINGUENEAU, 2013, p. 108).

E são os efeitos buscados pela reportagem, através do tom, da cenografia e do discurso aplicado, proporcionado pela convergência midiática, que analisamos com os corpora propostos neste artigo.

\section{Metodologia: comparando as construções e estratégias}

Para chegar às principais diferenças e semeIhanças dos dois vídeos, o primeiro, bruto, publi- cado na plataforma Youtube e a reportagem escolhida, este artigo é operada por metodologias de natureza descritiva, isto é, quando há apenas o registro e descrição dos fatos observados sem interferências do pesquisador nos objetos. A utilização desta abordagem buscou o estabelecimento de relações entre os dois vídeos. De acordo com Prodanov e Freitas (2013), esta

(...) observa, registra, analisa e ordena dados, sem manipulá-los, isto é, sem interferência do pesquisador. Procura descobrir a frequência com que um fato ocorre, sua natureza, suas características, causas, relações com outros fatos (p.52)

Já o procedimento metodológico utilizado é o comparativo, pois permite a análise de elementos abstratos e gerais entre os vídeos eleitos para a pesquisa. Prodanov e Freitas (2013) ressaltam que

Centrado em estudar semelhanças e diferenças, esse método realiza comparações com o objetivo de verificar semelhanças e explicar divergências. O método comparativo, ao ocupar-se das explicações de fenômenos, permite analisar o dado concreto, deduzindo elementos constantes, abstratos ou gerais nele presentes (PRODANOV; FREITAS, 2013, p. 37).

Com a natureza da pesquisa e a metodologia propostas, avaliam-se os corpora a partir desta etapa.

\section{Um Casey na internet...}

Casey Heynes já estava predestinado a ser um sucesso no Youtube. Reunindo elementos de grande aderência de usuários - violência e jovens - o vídeo que tem como principal enunciador um aluno da escola, foi postado na rede com uma sequência de cenas gravadas sob uma mesma perspectiva, sem o recurso de edição ou filtro de imagens, em um tempo exato de quarenta e dois segundos. O vídeo começa com a presença de quatro jovens portando mochilas, o que indica que se tratava do início ou do fim da aula. Não há 
elementos narrativos significativos, apenas alguns gritos que parecem ser de incentivo ao jovem Richard Gale, que na cena aparece de boné, agredindo Casey (fig. 2) pela primeira vez.

Figura 2 - Casey é provocado por Richard Gale

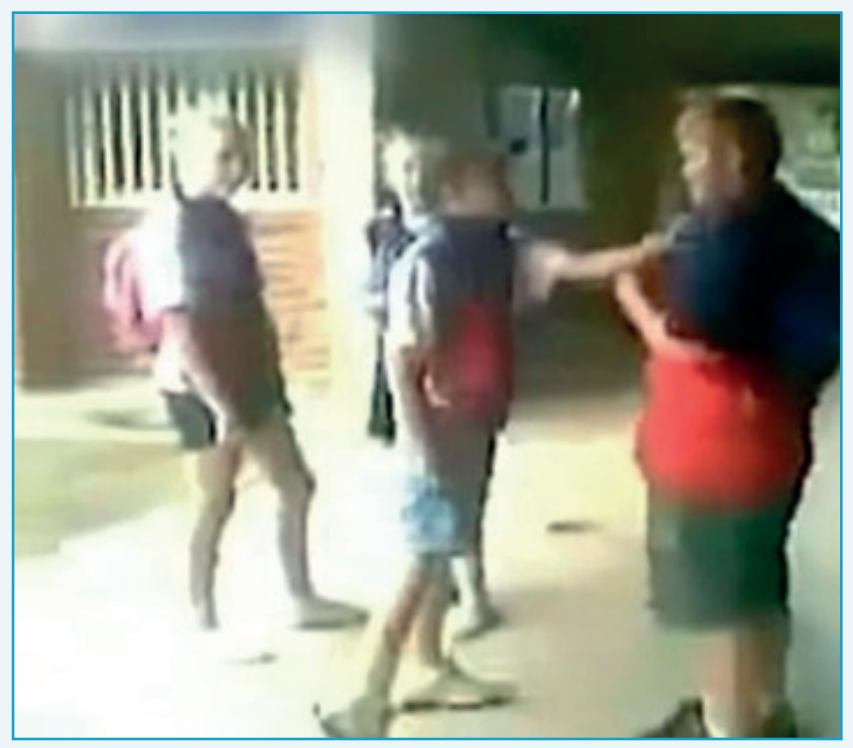

Fonte 2- Cena extraída do vídeo no portal Youtube

Neste trecho do vídeo, Richard questiona Casey sobre ter dito algo sobre ele. Richard usa um palavrão inaudível - aqui descrito por asteriscos ao questionar o outro:

Have you been talking ${ }^{* * *}$ ? Huh (sic)? (Richard) - Você andou falando algo, ${ }^{\star * \star *}$ ? Hein?

I haven't been talking, ${ }^{\star \star * *}$. (Casey) - Eu não andei falando nada, ${ }^{\star \star \star \star}$.

A luta segue e Richard passa a agredir Casey outras quatro vezes. O cinegrafista amador, que neste caso é outro aluno da escola, passa a assumir o papel de voz situada para além do texto. As falas que se seguem, inaudíveis, dão conta de um aluno que promove a situação em tom de narração de uma luta esportiva. É possível ouvir a sentença "Go, Richard, Go!", o que significa "Vai, Richard, Vai!", em um incentivo à briga dos jovens. Aqui se percebe o conceito de ethos de Maingueneau (2013), que diz que "por meio da enunciação, revela- se a personalidade do enunciador". Citando Roland Barthes, Maingueneau afirma que estes são os traços que o orador deve mostrar ao auditório, sem contar aqui sua sinceridade, para causar boa impressão. Isso significa que o jovem que grava as imagens quer ali incorporar a atitude de Richard, demonstrando claramente sua aderência às atitudes daquele que provoca Casey.

As demais palavras ditas são poucas, e o que mais se percebe são olhares espantados de quem se aproxima. Quase ao final do vídeo (fig. 3), já são seis pessoas assistindo à luta, quando Casey reage e aplica o golpe final no adversário.

Figura 3 - Casey aplica um golpe final no colega

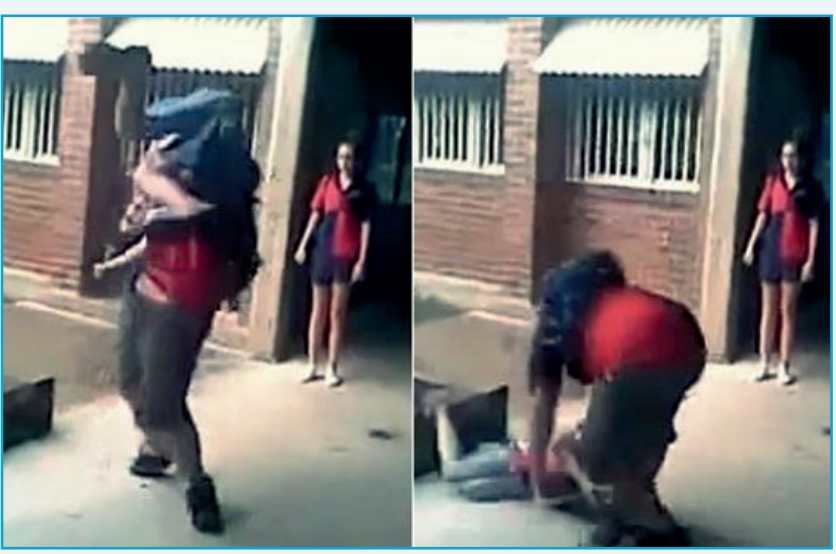

Fonte 3 - Montagem feita a partir de cenas do vídeo no Youtube

Esta sequência de imagens é permeada por um discurso formado por um processo de cenas validadas, que são apresentadas em concordância a um discurso e necessitam serem apresentadas para a compreensão do contexto. $O$ vídeo está ainda inserido na concepção de dispositivos comunicacionais como o Youtube e pode ser classificado como o de um produto midiático consumido em forma de gravação. Maingueneau (2013) afirma que

Podem-se igualmente distinguir os enunciados "espontâneos" que são concebidos em função de uma gravação (caso do político que fala sabendo estar sendo filmado pela televisão) e aqueles cuja gravação é feita de surpresa (MAINGUENEAU, 2013, p. 93-94)

Esta análise do vídeo permite concluir que este audiovisual possui linguagem de cunho amador, feita a partir do uso de um aparelho celular, 
sem maiores efeitos ficcionais e possui esta característica de surpresa, pelo menos a Casey, que em nenhum momento demonstra saber que está sendo filmado.

\section{Uma história aprofundada}

A comunidade australiana percebeu a história de Casey com mais nuances e detalhes quando o programa A Current Affair "pinçou" quarenta e cinco segundos de um vídeo sem legendas e transformou isso em uma reportagem de 12 minutos. Foi através disso que os telespectadores conheceram um pouco mais da história do garoto de 13 anos (à época) que, até então, já era visto como um herói por ter respondido a uma agressão culminada após provocações de bullying por parte de um colega na escola. Optou-se por analisar os principais quadros da reportagem, dissecados a seguir. É importante frisarmos que pelo tempo e pela construção que foram tecidas na reportagem, esta assume características de documentário televisionado. A seleção de imagens, os trechos da entrevista, a opção por este ou aquele depoimento, tudo faz parte deste gênero e tem o objetivo de prender a atenção do telespectador.

A matéria se inicia com um depoimento de Casey contando como a briga começou (figura 4 ao lado). A fala é pausada e Casey fala em tom tenso, relembrando o momento em que foi provocado. Este tom já confere ao jovem uma identidade de vítima de uma circunstância de pressão e ameaça. A reportagem usa como cenografia pequenos trechos do vídeo, a fim de legitimar a fala de Casey, ilustrando assim a veracidade de seu discurso. Toda a reportagem é marcada também por um selo superior de exclusividade, demonstrando assim o caráter único daquele depoimento a uma emissora de televisão.

Após detalhar a briga em todos os seus momentos, a reportagem passa a assumir características de documentário ao falar sobre a vida de Casey. Como cenografia para ilustrar supostos anos de abuso vividos pelo garoto, é feito o uso de fotografias de Casey quando criança (fig. 5). Esta cena, permeada por uma narrativa, carrega em si uma trilha sonora instrumental de característi-
Figura 4 - Casey fala à reportagem como foi intimidado pelo colega

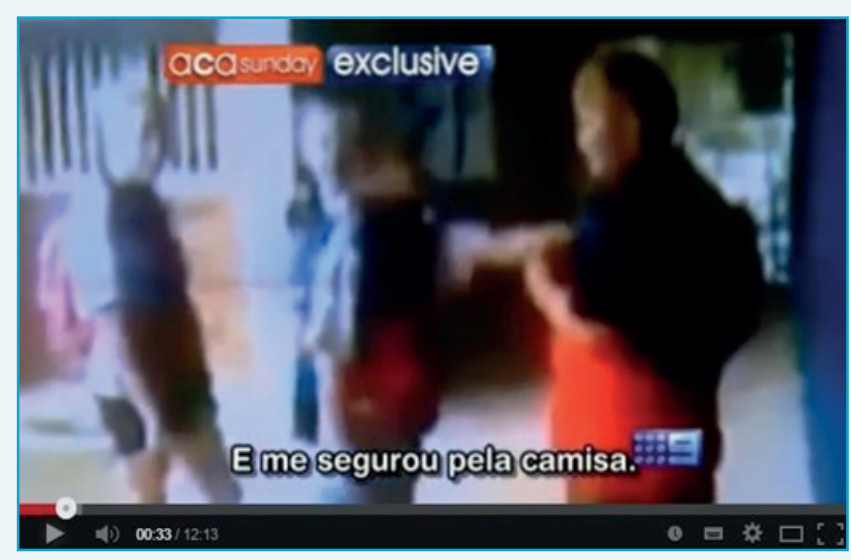

Fonte 4 - Cena extraída do vídeo no portal Youtube

ca dramática. O objetivo neste ponto é criar uma comoção por parte dos coautores sociais envolvidos na reportagem, neste caso, o público que a assiste.

Figura 5 - foto de Casey quando criança serve para ilustrar histórico de abusos

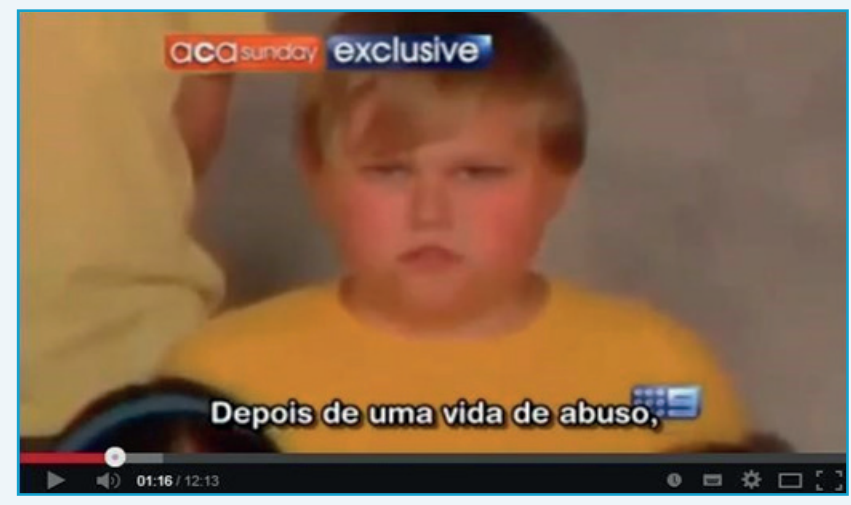

Fonte 5 - Cena extraída do vídeo no portal Youtube

Aqui vale destacar o olhar teórico de Charaudeau (2012), que aborda o efeito de contato da televisão que, ao utilizar-se de estes e outros elementos, pode criar a ilusão de que representa a verdade do mundo tal como ela é. Próximo ou distante, o mundo se torna presente, aumentando o efeito de ubiquidade. De acordo com o autor, além de criar um efeito de autenticação do acontecimento, cria

(...) um efeito de fascinação que pode fazer com que o telespectador, obcecado pela imagem do 
drama que lhe é apresentado, elimine o resto do mundo e o reduza à imagem que vê na telinha; e ainda um efeito de voyeurismo que pode fazer com que o telespectador tenha a impressão de penetrar em uma intimidade sem que a pessoa olhada o saiba (CHARAUDEAU, 2012, p. 112)

A reportagem segue e constrói um amparo de depoimentos para validar sua parcialidade a respeito da construção da imagem de um herói: através de um compilado de poucos segundos, veiculou pequenos fragmentos de mensagens enviadas a Casey ou de participações de programas de televisão onde o assunto foi discutido como principal pauta. Neste, especialmente, um grupo de mães qualifica a atitude de Casey (fig. 6) como de defesa e não de uma agressão. As mães não apoiam a atitude do menino como afirmam que, se a situação acontecesse em suas famílias, fariam o mesmo.

Figura 6 - depoimentos de mães em programa de debates reforçam apoio a Casey

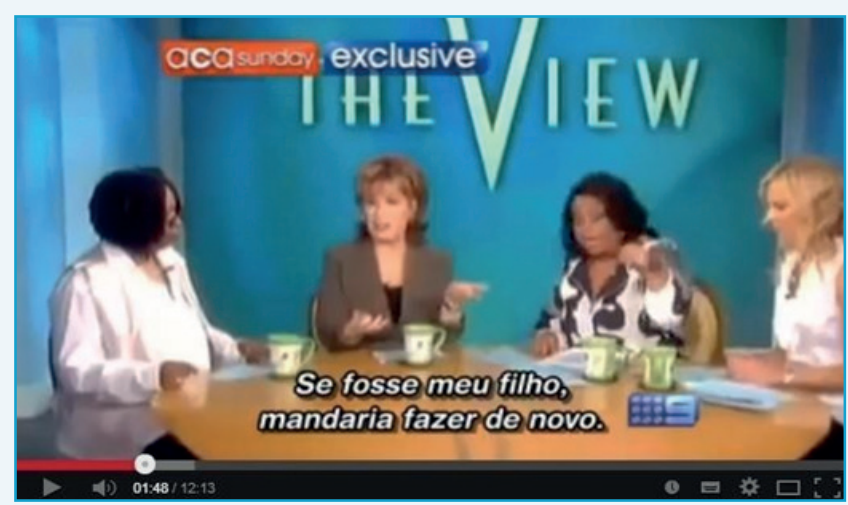

Fonte 6 - Cena extraída do vídeo no portal Youtube

Por meio desta enunciação e de outras semelhantes, Maingueneau (2013, p. 73) remonta à ideia de que o universo de sentido propiciado pelo discurso impõe-se tanto pelo ethos como pelas ideias que transmite. Segundo ele, "estas ideias se apresentam pelo intermédio de uma maneira de dizer, que remete a uma maneira de ser, à participação imaginária em uma experiência vivida".

Além de utilizar-se de fotos da infância de Casey e de câmeras aproximadas para registrar suas feições durante a entrevista, a reportagem procurou passar aos telespectadores outro ethos as- sociado a Casey: a de um menino frágil e dependente da família. Em certo momento, a cenografia utilizada é a de imagens do jovem com a irmã (fig. 7), tocando violão em parceria com ela.

Figura 7 - Casey toca violão ao lado da irmã

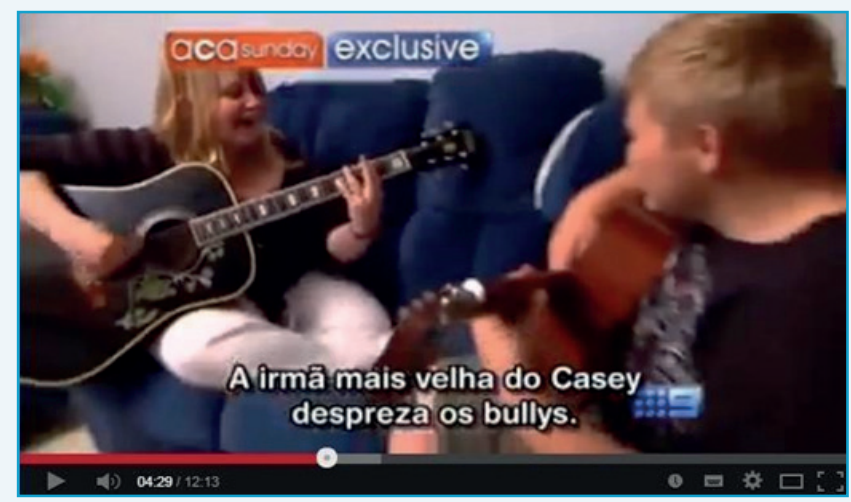

Fonte 7 - Cena extraída do vídeo no portal Youtube

Esta cenografia é apoiada em cenas de fala denominadas validadas. De acordo com o Maingueneau (2013, p. 102) estas cenas são validadas e significam que estão "já instaladas na memória coletiva, seja a títulos de modelos que se rejeitam ou de modelos que se valorizam". Isto significa que a abordagem ao momento em que Casey está com a irmã só vem a reforçar o apoio à conduta do menino, uma vez que passa a mensagem de que este é um garoto dócil, de boas relações familiares e que foi injustiçado pelo outro garoto em questão, ou seja, aquele que o provocou.

Neste ponto da matéria jornalística já é possível identificar o processo de convergência abordado por Jenkins (2009). Isso porque, de um pequeno fragmento de uma briga isolada, a emissora está contando uma história por diversas perspectivas, complementando aquele vídeo com muitas informações das quais o telespectador e até mesmo o internauta não dispunham até então. Supunha-se, pelo vídeo, que Casey estava se defendendo de uma situação. Mas a reportagem vai além e traz estes elementos complementares, que engendram uma situação familiar e de histórico de abusos muito mais complexa.

Os rastros discursivos da reportagem também entregam muito sobre a intenção daquela veiculação: contar uma história que cause empatia do telespectador, promovendo uma aderência 
ao discurso do menino. Durante vários momentos, as palavras reação, imposição e atitude demonstram o quanto o repórter e a emissora apoiam e avalizam aquela atitude. Em um determinado momento, um especialista em bullying reforça que os poucos segundos são suficientes para criar um sentimento de vingança em cada jovem que sofreu ou sofre com o bullying no mundo todo. Já em outra fração, a reportagem faz uma alusão à passagem bíblica do mito entre a luta de Davi e Golias (fig. 08), personagens da história do catolicismo que teriam duelado em plena desvantagem: Davi, um judeu de baixa estatura contra Golias, um perverso gigante. Na história, Davi derrota Golias com um golpe certeiro. Embora Casey tenha maior estatura e supostamente mais força que o outro jovem, a metáfora é utilizada para falar sobre a vantagem de um menino frágil contra outro mais valente.

Figura 8 - reportagem faz alusão à luta entre Davi e Golias

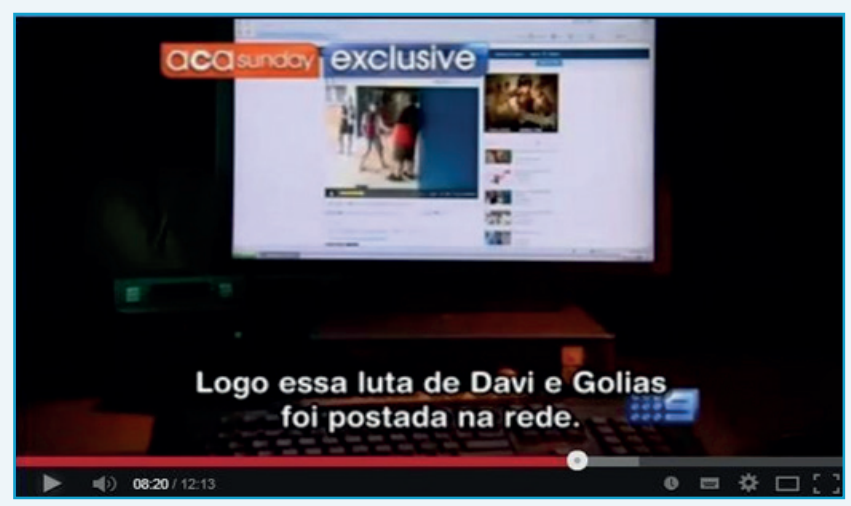

Fonte 8 - Cena extraída do vídeo no portal Youtube

Os depoimentos do pai e da irmã de Casey estão na reportagem como fiadoras do comportamento do jovem (fig. 9 e 10 ao lado). Elas legitimam a atitude de Casey perante o agressor. Embora pareçam inseguros sobre o que dizer ao entrevistador, ambos apoiam o a atitude violenta do menino. É possível visualizar em suas falas os rastros discursivos que permitem a interpretação deste apoio ao jovem, como nas expressões "toca aí" e o uso das palavras "feliz" e "defendido".

Deste momento em diante um especialista em vídeos no Youtube da emissora $A B C$ define o vídeo como um fenômeno cultural. Ele se apega à
Figura 9 - fragmento de depoimento da irmã em apoio a Casey

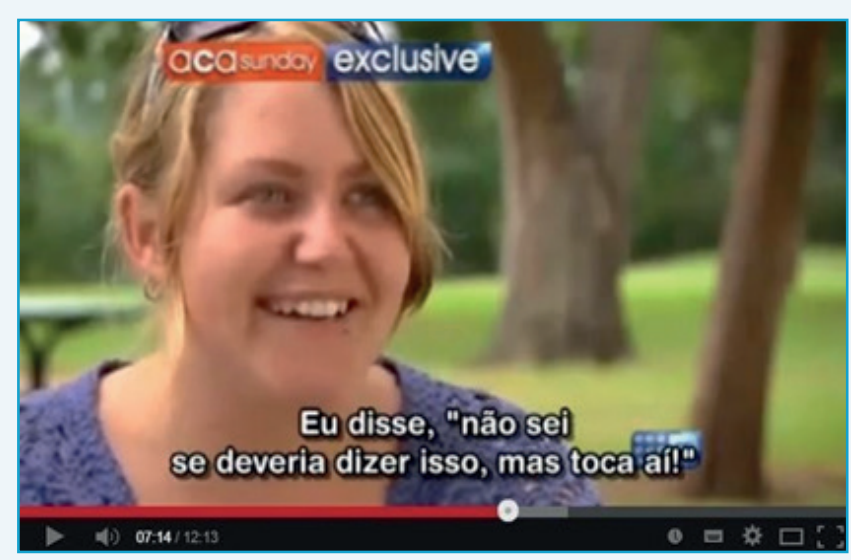

Fonte 9 - Cena extraída do vídeo no portal Youtube

Figura 10 - fragmento de depoimento do pai em apoio a Casey

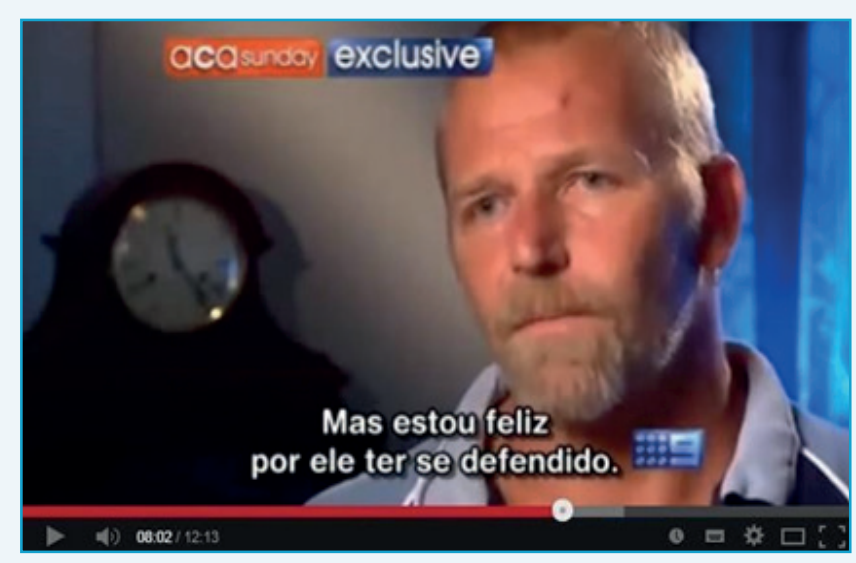

Fonte 10 - Cena extraída do vídeo no portal Youtube

memória coletiva para promover a ideia de que os poucos segundos do vídeo de Casey ultrapassam barreiras culturais, uma vez que pouco se entende do que é dito ou da cultura daquele ambiente em específico. Não se sabe, de acordo com o especialista, qual é a escola em questão, a cidade do ocorrido, os nomes completos dos envolvidos, a língua falada. Ele afirma que "fica claro quando ele vai atacar e quando ele faz, nos três segundos está uma fantasia de vingança, para qualquer garoto no mundo que já sofreu bullying".

Em uma das cenas finais, Casey afirma que se sente orgulho de ser uma referência para jovens vítimas de bullying. Na sequência, ele e a irmã surgem citando algumas destas manifestações (fig. 11), o que valida a fala do especialista em mídias. 
Figura 11 - reportagem apresenta depoimentos a Casey na página Facebook

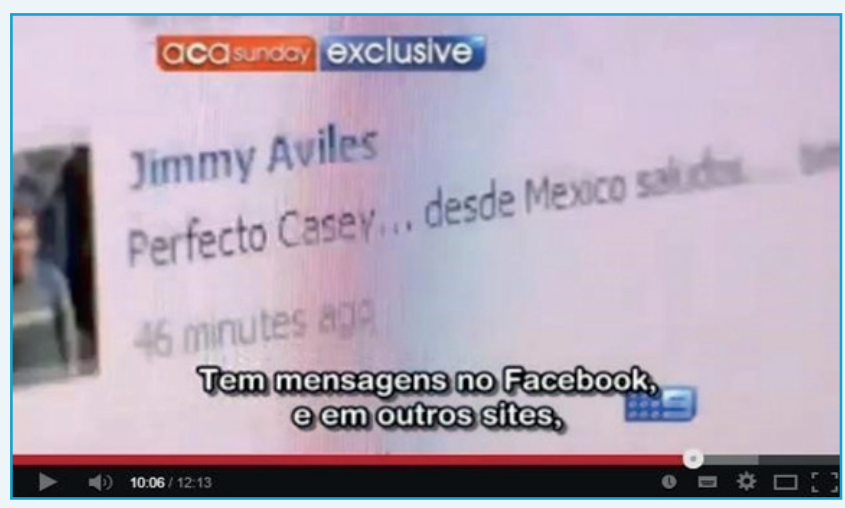

Fonte 11 - Cena extraída do vídeo no portal Youtube

Este é um dos principais pontos da reportagem. É aqui que fica clara a intenção de comover jovens no mundo todo, uma vez que a reportagem foi postada no Youtube e alcançou mais de cinco milhões de acessos. Apelando para o imaginário e as lembranças que permeiam a vida de pessoas que sofreram bullying na infância, o especialista em mídias sociais da emissora traz à tona o motivo de tanta comoção. No momento em que um profissional se posiciona, ele está ali legitimando a parcialidade do programa A Current Affair. Está transformando Casey em um herói para milhares de pessoas. Charaudeau (2012) fala da televisão como um dispositivo visual dotado do "choque de imagens". Para o autor, imagem e fala estão em solidariedade tal que não se saberia dizer de qual das duas depende a estruturação do sentido.

Segundo o autor,

É claro que cada uma dessas matérias significantes tem sua própria organização interna, constituindo um sistema semiológico próprio, cujo funcionamento discursivo constrói universos de sentido particulares, podendo a imagem jogar mais com a representação do sensível, enquanto a palavra usa da evocação, que passa pelo conceitual, cada uma gozando de certa autonomia em relação à outra (CHARAUDEAU, 2012, p. 109 e 110).

A reportagem se encaminha para o encerramento quando o repórter diz a Casey que mi-
Ihares de jovens devem estar se espelhando nele agora e o questiona sobre o que ele diria a estes jovens naquele momento. A resposta de Casey (fig. 12) é também uma inferência ao modelo que a reportagem quer vender: de que aquele jovem, do qual a emissora obteve uma entrevista exclusiva, é um modelo a muitos outros que passam pela mesma intimidação.

Figura 12 - depoimento de Casey sobre como os jovens devem agir

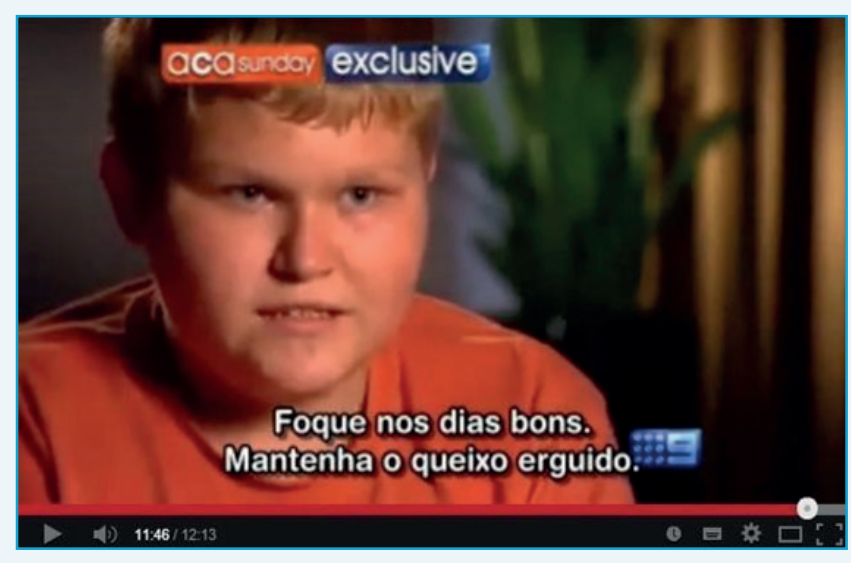

Fonte 12 - Cena extraída do vídeo no portal Youtube

Um final já esperado pelo tom impresso em toda a reportagem, nas quais foram utilizadas imposições vocais dramáticas e trilhas sonoras comoventes.

\section{Conclusão}

É preciso uma análise mais aprofundada dos elementos que compõem o vídeo bruto do caso Casey, mas pela análise da reportagem do programa A Current Affair, em comparação com este, é possível perceber que a matéria jornalística usou de inúmeros elementos para promover um ethos de herói ao jovem Casey. Seja pela escolha das imagens, das perguntas induzidas, das respostas escoIhidas, da trilha sonora, da ilustração com fotos de arquivo e da voz presente do entrevistador, fica clara a intenção da reportagem ao promover a personagem principal à posição heroica por sua atitude.

A convergência proposta por Jenkins (2009) existe no momento em que há um vídeo disponível no Youtube e através dele ocorre a narrati- 
va transmidiática, quando a linguagem televisiva complementa a da rede. Mas a convergência está muito além disso. Como o próprio autor que passar, ela existe no sentido de que há uma mudança e um impacto social no cérebro dos consumidores midiáticos.

Os conceitos de ethos, cenografia e rastros discursivos de Maingueneau (2013), bem como os efeitos de sentido que se quer passar, levando-se em conta os saberes do que interpreta (neste caso o telespectador) - uma concepção de Cha- raudeau (2012) - demonstram como as escolhas do editor-chefe do programa são fundamentais para a escolha da imagem que se quer passar a quem está em casa, calmamente sentado assistindo àquela reportagem. Este, confortavelmente receptivo e interpretante deste conteúdo, mal sabe que por trás de pouco mais de doze minutos está uma intenção arquitetada e esquematizada para tocar e fazer pensar de forma sistemática tal como quer a emissora. É o que "compra" uma imagem e dela se faz fiador. 


\section{Referências}

BURGESS, Jean. GREEN, Joshua - Youtube e a revolução Digital: como o maior fenômeno da cultura Participativa transformou a mídia e a sociedade. São Paulo: Aleph, 2009.

CHARAUDEAU, Patrick. Discurso das Mídias. São Paulo, Contexto, 2012.

JENKINS, Henry. Convergence culture: Where old and new media collide. NYU press, 2006.

JENKINS, Henry. Cultura da convergência. Trad.: Susana Alexandria. $3^{a}$ ed., São Paulo (2009).

LÉVY, Pierre, 1956 - O que é o virtual? / Pierre Levy - Tradução de Paulo Neves - São Paulo: Ed. 34, 1996.

MAINGUENAEU, Dominique. Análise de textos de Comunicação. São Paulo: Cortez, 2013.

PRODANOV, Cleber Cristiano. Metodologia do trabalho científico. [recurso eletrônico]: métodos e técnicas da pesquisa e do trabalho acadêmico / Cleber Cristiano Prodanov, Ernani Cesar de Freitas. - 2. ed - Novo Hamburgo: Feevale, 2013. 